Journal of Social Sciences (COES\&RJ-JSS)

ISSN (E): 2305-9249 ISSN (P): 2305-9494

Publisher: Centre of Excellence for Scientific \& Research Journalism, COES\&RJ LLC

Online Publication Date: $1^{\text {st }}$ July 2018

Online Issue: Volume 7, Number 3, July 2018

https://doi.org/10.25255/jss.2018.7.3.187.214

\title{
The effect of using facebook on improving English language writing skills and vocabulary enrichment among University of Jordan sophomore students
}

Manal Faleh Al-Tamimi*, Ahmad Hamad Al-Khawaldeh**, Hashem Ismail Mohammad AL Natsheh***, Amer Abdelqader Harazneh****

\section{Article History:}

Received date: 14th January 2017, Accepted date: 12th June 2018,

Published date: 1st July 2018

\section{Abstract :}

This study aimed to investigate the effects of using Facebook on improving English Language Writing Skills and Vocabulary Enrichment among University of Jordan Sophomore Students, and to answer the study questions:

Are there any statistically significant differences $(\alpha=0.05)$ in the writing mean scores of sophomore students that can be attributed to the teaching method (i.e. Facebook vs. conventional)?

Are there any statistically significant differences $(\alpha=0.05)$ in the vocabulary mean score of sophomore students that can be attributed to the teaching method (i.e. Facebook vs. conventional)?

To achieve the study goals and to answer its questions, a random sample was selected which consisted of (30) sophomore students from the University of Jordan and distributed to experimental group (15) students and control group (15) students. The control group was taught by the conventional way, while the experimental group was taught by the use of Facebook. Data were collected and analyzed to answer the questions using the pre-test, post-test, means and standard deviations, MANCOVA to check differences on pre and posttest for the dimensions of the test, ANCOVA to check differences on pre and posttest for total score, Test /Re-test to check the internal reliability of the test using person correlation.

Results showed positive effect of using Facebook on improving the students' writing skills and vocabulary enrichment of the experimental group, compared to the control group. Based on the results, the researcher recommended to focus on Facebook usage as a teaching and learning tool and motivating the teachers to adopt and apply Facebook in their writing and vocabulary teaching.

Keywords:

Facebook L82, Social Networks L14, Writing Skills A31, Vocabulary Enrichment P46.

Citation:

Al-Tamimi, M., et al. (2018). The Effect of Using Facebook on Improving English Language Writing Skills and Vocabulary Enrichment Among University of Jordan Sophomore Students. Journal of Social Sciences (COES\&RJ-JSS), Vol. 7, No.3, pp.187-214 https://doi.org/10.25255/jss.2018.7.3.187.214. 
* Jordan Food and Drug Administration, m_tamimi2008@yahoo.com

** The University of Jordan,

*** Al- Balqa' Applied University, Hashem.alnatsheh@bau.edu.jo

**** Al-Balqa' Applied University, amerharazneh@bau.edu.jo

\section{Introduction}

Recently, the use of social networking websites in the field of English language teaching and learning has increasingly attracted the attention of researchers. However, previous research has tended to focus on mass media and how they affect the field of English language teaching and learning. In this study the researcher focused instead, on social networking websites and trying to determine whether Facebook is critical and valuable resource for engaging students as active and social language learners.

Social media have offered marvelous opportunities for users to exchange ideas create discussions and develop their own content of interest conveniently. It creates a power to interact and make the world more open and connected. Due to many researchers' perceptions they have found that social media especially the social networking sites have great effect on the learning process and it creates space for autonomy according to the active role consumed by the learner. There are many examples of these platforms for instance blogs, micro blogs, wikis, Social networking sites, photo sharing sites, instant messaging, video-sharing sites and many more. These platforms have benefited billions of users from all over the world either from an individual perspective, professional level, companies or institutions (Noordeen, 2014).

Using Facebook as one of the most important social networking websites gives the opportunity to engage in interaction with social networking (Masa'deh et al., 2013). It is a place where people post their ideas, feeling, and information about themselves as a personalized web page. So student can interact and communicate with friends, family and meet new people from different countries. Recently it has become one of the leading social networking website in the world. In this study, the researcher discusses if Facebook improves students 'writing proficiency and if Facebook helps students to enrich their vocabularies.

This study investigates the current use of Facebook as a language learning tool in and outside of the EFL classroom in the process of learning writing skills and developing vocabularies in English by University of Jordan sophomores. On the other hand, this study explored the impact of groups created by the researcher on student's writing skills and enriching vocabulary and it showed the effects of using Facebook on the performance of writing and on the ability to communicate their thought in their writing, and how using Facebook as an attractive mean in communication, affects the quality of writing positively (Nunan, 2003).

Ibrahim (2013) pointed out that students nowadays have many concerns rather than studying and they are addicted to different kinds of technology. They like chatting with friends using their Facebook accounts which in turn make it easy to use Facebook in how to write effectively. He added that their academic performance in English, especially in 
writing is not proficient as it should be because they don't have the passion to learn through traditional methods. The researcher has found that it is suitable to exploit and take an advantage of their passion to chat with friends and their fondness to using Facebook to increase their enthusiasm and ability to learn effectively.

Vocabulary plays a central role in English language art instruction, so this study highlighted the effect of Facebook on enriching vocabulary through several activities. These activities gave students the chance to practice new words in a meaningful way, through creating monolingual groups, sharing posts or interact between students and teachers.

In the last few years, the output of social media networking specially Facebook has exploded both in English countries and anon speaking English countries so the researcher investigates to what extent Facebook affects writing skills and vocabulary enrichment (Benett, 2006).

English language as a main communication medium became a pre requisite and a provision for people to learn and master it. It has also become the basic language for business, technology and entertainment. This is noticed and evidenced from the extensive amount of academic and scientific research documented in English (Nunan, 2003).

English Language has an important role in several occupations, so several educational studies have confirmed the effective way to attain progress and advancement in language fluency and accuracy through reading and writing to improve these skills upon which the whole learning process depends (Haider and AKhter, 2012).

We are currently witnessing information and communication revolution called web 2.5, which is a living term describing the changing trends in the use of worldwide web technology and web design that aims to enhance creativity, information sharing, collaboration and functionality of the web. Web 2.5 concepts have led to the development and evaluation of web-based communities and hosted services such as social Networking sites, video sharing sites, Blogs and other sites like Facebook. (Fernandez \& Sabirwal, 2014; ALsarayreh,et all,2011; Mohammad et all,2011)

In 2004, Facebook was launched as a social network that offered school members access to the profiles of other classmates. It enables users to keep personal profile and interact with other people, keep-up with their friends, and send and receive messages and learn about people with who on they meet (Thompson, 2008).

One of the most remarkable features of Facebook is its "stickiness" in that two thirds of its total users' base comes back to the site during the day. Using Facebook as an emerging media for communication is considered one of the most important social networking sites that provide people the access to others without any boundaries (Benett, 2006). 
This study investigates whether Facebook works to improve writing skills and provides them with the opportunity to gain and enrich their vocabulary content. Hence, the study works to investigate the current use of Facebook as a tool for learning and teaching, inside and outside the classroom settings for the University of Jordan sophomore students. In addition, to explore the impact of the group created by the researcher to help to use language in communication. On the other hand, to what extent using Facebook is considered an attractive mean for the students to improve the quality of writing and enriching vocabularies.

\section{Statement of the problem}

Facebook is currently considered the most popular online social media site used by millions of students and adolescents for a variety of purposes, but with the heavy emphasis on social needs. The younger generation is spending more and more time on Facebook, so the problem with such technological development is how students should consider these valuable sites especially Facebook for educational purposes. Some researchers indicate that the use of Facebook makes learning easer in the formal education and has the potential to enhance their learning process (Roblyer, 2010).

As a result, instructors, educations and curriculum developer have the task and responsibility of educational environment to benefit from the new trends in education by using the opportunities offered by Facebook to improve the students' English learning through interaction and communication with teachers and students at the university level.

From the researcher's contacts with university of Jordan students, she noticed that students use Facebook to learn vocabulary via their courses from each other and from other sources. University professors encourage students to benefit from social media in their learning. English department students can benefit from using Facebook in their Writing course. Advance writing is a course administrated to $2^{\text {nd }}$ year university students. This study attempts to measure the effect of using Facebook in students' writing development.

\section{Purpose of the Study}

This study aims to explore the effect of using Facebook on improving English Language writing skills and vocabulary enrichment among the university of Jordan sophomore students, and the collective results of their academic performance and achievement using the Facebook as instructional method. On the other hand, the new teacher roles identified here as an instructional designer, trainer, collaborator, silent partner, team coordinator, advisor, and monitoring and assessment specialist. Each role was associated with specific activities and was made possible by the use of social media in education.

\section{Questions of the study}

From the statement of the problem emerge the following two questions:

1. Are there any statistically significant differences $(\alpha=0.05)$ in the writing mean scores of sophomore students that can be attributed the teaching method (i.e. Facebook vs. conventional)? 
2. Are there any statistically significant differences $(\alpha=0.05)$ in the vocabulary mean score of sophomore students that can be attributed to the teaching method (i.e. Facebook vs. conventional)?

\section{Significance of the study}

The importance of the study stems from the point that Facebook usage is a relatively new field regarding its use which constitutes a cognitive base among the social media networks, so it is important to direct the students toward using Facebook site to be able to attain the desired results through enriching their writing skills and vocabulary content. The focus should be on altering or modifying the students' practices and attitudes towards using Facebook to facilitate and organize their learning process.

Significance of this study can be summarized in the follows points:

1. This Study is expected to enhance the writing skills of the university of Jordan sophomore students, and improve the students' academic performance.

2. It has the potential to provide the educators and the policy makers, curriculum planners with a clear picture about the nature of using such social media tool to attain the positive effect.

\section{Operational Definitions of Terms Facebook}

Facebook is social networking website defined by Browse (2009) as a popular free social networking website, it allows the registered users to perform several functions, ranging from creating profiles, uploading photos, videos, sending and receiving messages, keep in touch with friends, peers, colleagues, and other significant persons to exchange ideas, opinions experiences and experts. In addition to create discussion forums, in this study, the effect of Facebook on improving English Language writing skills and vocabulary enrichment among university of Jordan Sophomore students will be investigated. Facebook was founded in 2004, and within 24 hours of its launch nearly (1500) Harvard students had registered on the site and Facebook soon expanded to include other colleges.

\section{Sophomores}

Are the second year students at the University of Jordan, who will participate in this study, they were divided into control and experimental group.

\section{Social Media Networking}

Social media networking refers to those systems that enable the members register in a specific site to know the skills, talent, and the preference, specific to other persons (members), such networks include, Facebook, MySpace Linkedh\& Twitter used by many users for different purposes. (Fernandez and Sabeerwa, 2014: 358). In this study, the target social media is Facebook effect on certain variables.

\section{Academic Achievement}

Achievement is the result of what the student has acquired of knowledge, information and practice during his education. In this study, the University of Jordan sophomore 
students and their average at the end of the academic year, or the accumulative average of the university students in the $2^{\text {nd }}$ term before applying this study, the achievements of the participants will be considered as the dependent variable.

\section{Limitations of the study}

Temporal limitations: This study is limited to be accomplished during the period (20162017).

Spatial limitations: This study is limited to the University of Jordan.

Participants in this study are the sophomore students at the University of Jordan exclusively.

One instrument was used in this study, namely the writing and vocabulary test.

\section{Theoretical Framework}

The few past decades have witnessed a tremendous revolution in the Internet and other social media usage, since they made great chance in the social, economic and political relations in the world generally and in Jordan specifically.

There is an agreement among the researchers and social experts that the Internet and social media opened a new era of direct and indirect interaction between the society individuals and other humans in different parts of the world. This include exchanging of the ideas and information to know about the cultures, norms, traditions and values modes, transforming the world to a global village and global family (Al-Azza , Atameeni and Al-Qatawneh., 2004: Alananzeh et all,2015).

They facilitate interaction and knowledge about everything taking place in the world. It's a mean for interaction and exchange of information and pictures through social networking sites, these sites became the appropriate place to disseminate the opinions and the ideas, they form a wide platform of social communication without constraints or limits (Mak'awi and Al-Sayed, 2003: 188-191).

\section{English Language Writing Skills and Vocabulary Enrichment}

Teaching English as a foreign language (TEFL), in countries where English is not the first language encounters lots of difficulties. They range from students' reluctance and shyness to frustration due to inability to properly produce and use it in the classroom; Facebook helps the student and prompts him to initiate or to carry on with a conversation but the case is not the same in the conventional method. The ultimate goal of teaching English as a foreign language (TEFL) is to enable students to communicate in English. In order to be able to communicate, teachers should emphasize on the four language skills in the English language classrooms. With extensive focus on the reading and writing skills to ensure that students are communicatively learning these skills (Jayyusi, 1990).

Vocabulary learning can be achieved through reading is a skill that includes all other language skills. To be able to read English as a foreign language (EFL) it means to focus on text processing and on the readers' understanding of the text. While to practice this skill successfully, students will be able to read for comprehension, learn new words in the 
context, practice grammar, communicate, interact and not only following rubrics. Because reading is a skill that helps in mastering other language skills, as a result the need for using computers to support new reading strategies seems essential (Rumelhart, 1977).

Writing is another essential skill in foreign language learning that aims at giving the learners the opportunity to develop the proficiency they need to write personal letters, essays, and research papers. In addition, writing skills enhance cognitive and linguistic awareness (Jayyusi, 1990).

\section{The Process approach to writing}

The process approach to writing is a positive innovation allowing teachers and students more meaningful interaction and more purposeful writing. It is a complex process; it is not linear; it is recursive and involves a number of sub-skills, Writing can be learnt through experience. Ada and Campoy (2004: 4) confirmed this idea adding that writing is approached as a well-structured set of rules and regulations concerning choice of words, appropriate grammar, punctuation and tone. They stressed the relation between writing and thinking indicating that writing is presented as a vehicle for reflecting on who we are, not as a possibility for expressing ourselves forcefully, without fear of judgment." Writing can only be learnt well through writing. It is found that learners pass through the same stages professional writers go through, thus it involves training, instruction, practice, experience and purpose.

A good reader is a good writer; this is why Ada and Campoy (2004:.6) suggested for teachers whose aim is to develop the voices of their own students to "read to them and with them". Johnson (2001: 288) believed that the major writing process phases are specified by White and Arndt (1991, p.4), also featuring the cyclical relation among the various phases in addition to illustrating the recursive and nonlinear attribute of the writing process.

The writing workshop has emerged from the writing process; it is an ideal example of student- centered learning environment. Woolfolk (2001: 340) pointed out that "group work can be useful, but true cooperative learning requires much more than putting students in groups." The effectiveness of the writing workshop depends on cooperative learning.

Many specialists in the area of methodology argued that the writing workshop succeeded when students were immersed in the writing task and they had free opportunities to choose their topics. During the process of writing students engage in asking question, talking with peers and teachers. Such affective involvement helps students achieve better standard of writing which inevitably leads to positive attitudes and self-realization (Calkins, 1994; Ray, 2002 and Zamel, 1987).

Anderson (2000) explained that through the writing workshop, individual teacherstudent conferences give good opportunity for teaching. Such individual private tutoring does not hinder the flow of expression of other students who are working independently. 
In the writing workshop the teacher plays an important role: through the use of modeling sessions or mini-lessons; conducting conferences with the learners; allowing students fair time to work independently until they are capable of reaching the point to publish their writing.

The instructor's role is indispensable to the success of the writing programme, the students need a teacher who can provide expert modeling for good writing and reveal him / herself as a person who writes for a real purpose. The teacher can write for five minutes or so in the writing workshop, he needs to monitor and guide students as individuals, pairs and groups, to engage in evaluating their writing assignments and push them for deeper understanding and reflective and critical thinking (Zamel, 1987; Graves, 2003).

Rigid classroom and physical environment may add an intimidating state to the writing task unless the new strategies prove appealing to the students. One of the most important strategies which might encourage everyone to write in the writing workshop is applying the writing conference, so conferences are in the heart of our teaching (Calkins, 1994: 189).

During the writing workshop, peer conferring is initiated by the students themselves while response groups are formed upon the teacher's request. Allowing the students, the chance to respond to each other's writing creates a natural audience (Zamel, 1987). The student who works as a facilitator sets the agenda and decides whom to help and how after reading the piece of writing. Peer conferences are usually fiveminute talk about writing in progress emerged from the process approach to writing. (Calkins, 1994: 190)

The writing conference is one of the most areas heavily used techniques and strategies in the writing process approach. This might be due to the attitude to build lifelong learners; there is a need for learner-centered classroom. Researchers who examined teacherstudent writing conference had supported the principle that such conferences support the language acquisition (Anderson, 2000).

\section{The Effect of Facebook on Teaching English Language}

Bani Hani (2010) realized the importance of using Facebook for the instructor in minimizing time and effort, raising his efficiency, changing his role and knowing the individual differences between the students. On the other hand, using Face book attracted the students 'attention and focus, motivating him, making him asocial learner and achieving more continuous learning and sustainable effect. Accordingly, the student can overcome the risk element and the temporal and spatial dimension.

There are many reasons that have led to the urgent use of Facebook in teaching which include the following: (Morad, 2004: 29):

Learning languages is considered one of the topics with urgent need to use the educational means, since the words and the phonetic symbols might represent absolute expressions, their meaning clarity to the individual depends on what he has of sensory 
experiences which link with these words, and educational means work to link the written words with their meanings and the spoken words and sounds in their appropriate pronunciation.

\section{Literature Review}

Yonus and Salehi (2012) examined the effectiveness of Facebook Groups on teaching and improving writing: students' perceptions attempts to explore the student's perception on the effectiveness of Facebook groups for teaching and improving writing. Study sample consisted of (45) third year students completing their bachelor's degree in TESL, in the faculty of education, university of Kebangsan- Malaysia. The authors used the questionnaire for data collection from the respondents and measured their perceptions. The questionnaire consisted of (10) close-ended items and (3) open items. Results of this study showed that Facebook groups in an effective tool in improving the students writing skills especially in the brainstorming of ideas before the actual reading.

Arroyo (1992) conducted a study to examine the effect of extended use of computers on reading achievement. The subjects consisted of (75) grade seven students attending an elementary school located in a predominantly low-income socio-economic neighborhood of South Chicago. From this total, (15) students were subjected to an intensive computer assisted instruction programme for the entire school year, while (15) others, randomly selected from the remaining group of (60) received no computer training and served as a control group. Results of the lowa Tests of Basic Skills indicated a statistically significant increase in reading achievement of the students who used computers. In addition to an improvement in reading scores, Arroyo also points out that use of the computer appeared to increase student motivation to learn.

Lee (2003) described a classroom inquiry which investigated the teaching of coherence by using CALL. In this study, coherence was defined in terms of a number of coherencecreating devices, and pedagogical materials were designed accordingly to teach the concept to a group of (16) English students as second Language high school students in Hong Kong. Data were collected from their pre- and post-revision drafts, think aloud protocols during revisions, as well as post-study questionnaires and interviews. The findings indicated that at the end of the explicit teaching of coherence, students improved the coherence of their writing and directed their attention to the discourse level of texts while revising. They also felt that the teaching of coherence had enhanced their awareness of what effective writing should entails.

Hussain and Ghoul (2014) studied the impact and effectiveness of using Facebook on the English language achievement of the ninth grade students in Jordan. The study was conducted in Asia secondary school for Girls in Amman in their first semester 2014/2015, to study the effect of accumulative average and the interaction between them. Study sample consisted of (68) students divided in to two groups, one was an experiential group (33) students studied by the Facebook way and the other was control group (35) students studied the same unit in the traditional way. Study instruments used were educational materials and a comprehensive and reliable test was designed and applied as a pre-test and a post-test after the completion of the study unit. The two groups in favor 
of the experimental group in the accumulative average. The study concluded with a set of recommendations. The most important were using Facebook in the elementary education to help the students using e-learning, and drawing the attention of English curriculum authors for the need of using Facebook to benefit from its properties in enriching the curriculum with modern technologies.

Rodliah (2015) study investigated how Facebook can be incorporated in ELT through edialogue Journal writing sharing in a Facebook closed group. Fifteen EFL students participated in this study they were second, third and fourth year students of English education department of a university in closed group for four months. Results of the study indicated that the students responded positively to this activity and perceived improvement in their writing especially in vocabulary and grammar.

Alkhader (2015) explored the impact of using the social networking Facebook site on improving academic writing skills and reflective thinking of university of Jordan students. The study sample consisted of (79) students (35) students for the experimental group and (44) students for the control group, the instruments of the study was Academic writing test, Reflective thinking test and Focus group open ended interviews. Result of this study was in favor of the experimental group which indicates that Facebook does improve rhetorical writing skills mainly and linguistic writing skills and on the other hand using Facebook didn't have significant impact on other writing conventions as grammar and vocabulary.

Ahmad (2016) investigated the effect of Facebook on grammar discussion and writing skills in English. The study sample consisted of (60) students (30) students for the experimental group and (30) students for control group, the instrument of the study was an EFL grammar and writing tests. Students in both groups were Pre-tested using the EFL grammar and writing test. After that the experimental group was taught using Facebook while the control group was taught using the traditional method. Results of the study showed that the experimental group outperformed the control group in the post - test of EFL grammar and writing.

\section{Key points that emerged from the Previous Studies}

1. Most of the studies related to Facebook have been conducted in the recent years, while indicated to the novelty of the topic and the interest in it by the researchers from different countries.

2. The conducted previous studies had different objectives and goals to achieve, some studies aimed at investigating the effect of using Facebook on improving the students' language skills in learning English language as a foreign language, such as the relationship between using Facebook and improving reading, writing, grammar and comprehension skills. Other studies aimed to investigate the students' motives to use Facebook to communicate with each others and with their teachers.

3. Some of the previous studies used the descriptive method while other studies used the experimental analytical method with different targeted students. 
Methods and Procedures

Participants of the study

The participants of this study were randomly chosen from University of Jordan English Department 2 nd year students. These subjects were 30 sophomores majoring in English language. They were randomly assigned to an experimental and control group (15) for each. The experimental group was exposed to an instructional programme based on Facebook group, whereas the control group was exposed to the conventional programme.

Table (1) Sample distribution according to the two groups

\begin{tabular}{|c|c|c|}
\hline Group & Percentage & Student Total \\
\hline Experimental & $50 \%$ & 15 \\
\hline Control & $50 \%$ & 15 \\
\hline Total & $100 \%$ & 30 \\
\hline
\end{tabular}

Table (1) showed the total number of the student is thirty. Fifteen students are in the control group and fifteen are in the experimental group.

\section{Research instruments}

The following three research instruments were used to achieve the purpose of the study. For data gathering and to answer the study questions, pre -and post- tests were conducted on a sample of (30) sophomores and feedback scores was used to collect quantitative data.

\section{Writing Test}

A Writing test was development by the researcher, to measure the students' level in writing proficiency before and after the experiment. The writing test had 25 marks as a total score. The test contains writing a topic about Centennial of the Great Arab Revolution (see Appendix 6 part 2).

\section{Vocabulary Test}

The researcher designed a test to measure vocabulary enrichment as a result of using the proposed programme. The test contained multiple-choice, matching antonyms a synonyms and fill in the blanks questions. These vocabularies were selected according to different topics in which these topics were chosen by the instructor and the students.

\section{Difficulty and Discrimination of the writing and vocabulary tests}

The difficulty and discrimination of the writing and vocabulary tests were obtained as they are in the following table: 
Table (2) Coefficients of Difficulty and Discrimination of the writing and vocabulary tests

\begin{tabular}{|l|c|c|}
\hline \multicolumn{1}{|c|}{ Dimension } & Difficulty & Differentiation \\
\hline Organization of the writing topic & 0.53 & 0.75 \\
\hline Voice of the advanced writing course students & 0.44 & 0.674 \\
\hline Word choice adopted by the students & 0.46 & 0.715 \\
\hline Sentence structure & 0.46 & 0.638 \\
\hline Content of the writing topic & 0.43 & 0.620 \\
\hline Total score & 0.46 & 0.680 \\
\hline Vocabulary & 0.66 & 0.472 \\
\hline
\end{tabular}

Table 2 shows that difficulty coefficients ranged between $(0.44 \& 0.53)$ which are relevant difficulty values, all ranged between Discrimination coefficients ranged between (0.66) which are relevant values, all reached greater than $(0.40)$ and for vocabulary reached (0.472).

Validity and Reliability of the writing and vocabulary tests:

The validity and reliability of the two instruments were established, using appropriate statistical methods to achieve this purpose.

To obtain the validity, the test was presented to a group of jurors from university professors to gather their comments and suggestions.

Test re- test was used to test the reliability of pre and posttest.

\section{Validity of the instruments}

The researcher sent nine copies of the test to nine professors. Those professors are from Department of English language of the Faculty of Arts and from Curriculum and Instruction Department of the Faculty of Educational Sciences, to confirm the validity of the test according to the questions of the study. The items of the test were modified according to jurors' suggestions.

One example of such modification was question (4) on the vocabulary test" Choose the correct term by placing the letter of the correct answer in the blank preceding the definition ". This question was before the modification; "Choose the correct term by placing the letter of the correct answer in the blank preceding the question".

Another example of the modification regarding the writing question on the writing test "Write a well-organized paragraph on the following topic. Express yourself as much as you can. Your paragraph should contain approximately 150 words".

This question was before the modification; "Write a well-organized paragraph for ten to fifteen minutes on the following topic below. Express yourself as much as you can. Your paragraph should contain approximately 150 words". 


\section{Validity of the Instructional Programme}

To obtain the validity, the Instructional programme was presented to a group of jurors of university professors to gather their comments and suggestions. To confirm the validity of the instructional programme according to the questions of the study. The programme was modified according to jurors' suggestions.

\section{Validity of the writing rubric}

The researcher developed writing test rubric after reviewing the rubric contents. Test rubric contained five dimensions: organization of the writing topic, voice of advanced Writing course students, content of the writing topic, word choice adopted by the students, sentence structure, grammar, mechanics and spelling used by the students (See Appendix 3, 4).

\section{Reliability of the instruments}

For the purpose of ensuring the reliability of the two instruments, a re-test was used to test the reliability of control and experimental test

Reliability of the test was verified through the test - retest method on a pilot sample of 15 students who were randomly selected from outside the study sample.

\section{Test Re-test Reliability}

Test re- test Reliability is confirmed by applying the scale to (15) students from outside the study sample, and re-applicant ion after two weeks, Reliability coefficients by re-test way reached as explained in the following table:

Table (3) Coefficients of reliability by test - retest of the writing and vocabulary tests

\begin{tabular}{|l|c|}
\hline Dimension & Re-test Reliability \\
\hline Organization of the writing topic & 0.718 \\
\hline Voice of the advanced writing course students & 0.773 \\
\hline Word choice adopted by the students & 0.812 \\
\hline Sentence structure & 0.844 \\
\hline Content of the writing topic & 0.732 \\
\hline Total score & 0.918 \\
\hline Vocabulary & 0.912 \\
\hline
\end{tabular}

Table 3 shows that Reliability coefficients by the re-test way ranged between $(0.718$ $0.854)$ and for the total degree $(0.918)$, and the vocabulary re-test Reliability $(0.912)$, which are relevant Reliability values of indicate to the scale's Reliability.

\section{Procedures}

The researcher used a diagnostic pre- test for evaluating the level of the students and a post-test for observing the differences in the students ' performance in writing quality .The post test was applied to both groups, the experimental group and control group. The study was conducted in the summer semester of the academic year 2016-2017 at University of Jordan, Department of English according to the following Procedures:

1- Getting the approval of University of Jordan to conduct the study. 
2- Reviewing the related literature.

3- Selecting the participants of the experimental and the control group.

4- Administrating the writing and vocabulary pre- test for both groups of the study.

5- Choosing a lab in Language Center, with good head phones

6- Establishing the web page on Facebook site:

7- Establishing a group on the webpage on Facebook site:

a. Each student made a friend request for the web page.

b. Choosing a name for the selected group related to the name of the course.

c. Choosing a cover photo and profile picture for the group.

d. Designing a slogan for the group.

8- Using Technical tools for designing the web page on Facebook site:

a. The researcher used Photoshop programme. Graphic design was one of the most important tools for designing the web page.

b. The researcher used Microsoft word application in which words and grammar were corrected automatically.

c. Up lauding writing documents (files) to the wall or to the mail box of the teacher.

d. Downloading essays, activities and instruction from the page to the desktop.

e. The researcher shared a link for a dictionary to help students to define words and vocabularies.

9. Designing an instructional programme on a webpage which includes a group of $2^{\text {nd }}$ Year University of Jordan Students created by the researcher with cooperation with the instructor and the lab technician in light of the related literature.

10- Assigning group/peer correction tasks

11- Conducting group chatting outside the lab.

12-The instructor met the students four times a week for 40 days.

13-Through this period of time the instructor offered some tasks in which the students were allowed to post their pieces of writing on the instructor's web page, according to different groups of vocabulary of different topics provided by the teacher in his main page and they practiced these vocabularies in which students were able to build their paragraph and typically produce words, practice making word combination and trying to answer the clue questions posted by the instructor on the web page before writing the paragraph.

14-The instructor tagged pieces of writing on the students " page to find the equivalent words of the underlined words and sent them directly to their colleagues to share experience with each other and then automatically posted the paragraph on the main page of the instructor.

15-Approximately Each 4 days a specific topic had to be covered with the students. For monitoring these procedures, the instructor created a list of these tasks after receiving them from the students and listed them with time and date, and then a feedback was sent from the instructor to the students about these tasks.

16-The assigned tasks were from Advanced Writing course of the 2nd year students of the English Department at the University of Jordan who take Advanced Writing as an obligatory course 


\section{Stages of building the Instructional Programme \\ Stag 1: Analysis}

The first stage of the this model includes, identifying objectives of this instructional programme on Facebook site, problems related to the students' needs, values, knowledge and ideas about the topic should be taken into account in this teaching environment. Also there is the need for identifying the teaching methods used in this instructional programme. On the other hand this stage identifies the characteristics of the learners and their desire and readiness to learn through Facebook. Interviews were conducted for this purpose.

\section{Stage2: Design}

Designing educational components and choosing a method for creating these components. This transforms information in the analysis step and developing it into a specific design on Facebook site.

\section{Stage 3: Development}

In this stage, the information from previous steps was turned into an actual instructional programme, where the programme begins to take its final shape.

\section{Stage 4: Implementation}

The developed instructional programme in the first three stages is now put into action. This is the step where the actual instruction and learning take place. Then the Instructor will be able to implement the programme, the implementation stage develops procedures for training instructors (facilitators) and learners. Training facilitators cover the course curriculum, learning outcomes, and testing procedures. Preparation for learners includes training them on new tools and student registration. Implementation includes evaluation of the design.

\section{Stage 5: Evaluation}

Evaluation is an important ongoing process for the designing of the programme on the Facebook site. There are two ways of evaluation: Formative and Summative. The Formative evaluation exists in each of the previous steps in the model. Each step is evaluated to get feedback to the user of the instructional programme, while the Summative evaluation process is about evaluating the programme according to the feedback received from students. The programme might be modified as required.

There are advantages of this developed model including the following:

It can be used in many ways to meet the needs of any instructional environment, and adding feedback at each stage, allowing the model to be followed rapidly.

Finally, the instructor's task was to administrate the whole work including correcting, commenting, and giving suggestions for presenting ideas in a better way.

\section{Statistical analysis}

To answer the questions of the study, the researcher used the following statistical measures:

1. Means and standard deviations to check differences on pre and posttest. 
2. MANCOVA to check differences on pre and posttest for the dimensions of the test.

3. ANCOVA to check differences on pre and posttest for total score.

4. Test /Re-test to check the internal reliability of the test using person correlation.

Variables of the study

The study contains the following variables

The independent variables:

The independent variable was the teaching method, which has two levels: using Facebook vs. the conventional method.

The dependent variables:

The total grades for the post-test after using Facebook in teaching writing skills.

The total grades for the post-test after using Facebook in vocabulary enrichments.

\section{Design of the study}

This study is quasi experimental; in this design, the researcher divided participants into an experimental group and control group. Before undertaking the experiment, both groups took pre -tests to measure their proficiency in writing skill and vocabulary enrichment. After conducting the experiment, the same test was repeated as post- test to investigate any significant differences between the groups.

The design of the study is portrayed as follows:

Where:

EG: Experimental group.

CG: Control group.

01: Writing test.

02: Vocabulary test.

X: Facebook treatment.

\section{Results of the study}

\section{Results related to the first question}

Are there any statistically significant differences $(\alpha=0.05)$ in the writing mean scores of sophomore students that can be attributed to the effect of the teaching method (i.e. Facebook vs. conventional)?

To answer this question, means and standard deviations were calculated on pre and post measure of the writing measure dimensions according to the teaching method between the control group and the experimental group.

Table (4) Means and standard deviations of the pre and post measure of both groups with regard to the writing dimensions according to the teaching method

\begin{tabular}{|c|c|c|c|c|c|c|}
\hline \multirow{2}{*}{ Dimensions } & \multirow{2}{*}{ Group } & \multirow{2}{*}{$\mathbf{N}$} & \multicolumn{2}{|c|}{ Pre test } & \multicolumn{2}{c|}{ Post test } \\
\cline { 4 - 7 } & & & Mean & $\begin{array}{c}\text { Std. } \\
\text { Deviation }\end{array}$ & Mean & $\begin{array}{c}\text { Std. } \\
\text { Deviation }\end{array}$ \\
\hline Organization of the & Experimental & 15 & 1.67 & .976 & 2.80 & .862 \\
\hline
\end{tabular}


The effect of using facebook on improving English language writing skills...

\begin{tabular}{|c|c|c|c|c|c|c|}
\hline \multirow{4}{*}{ writing topic } & \multirow[b]{2}{*}{ Group } & \multirow[b]{2}{*}{$\mathbf{N}$} & \multicolumn{2}{|c|}{ Pre test } & \multicolumn{2}{|c|}{ Post test } \\
\hline & & & Mean & $\begin{array}{c}\text { Std. } \\
\text { Deviation }\end{array}$ & Mean & $\begin{array}{c}\text { Std. } \\
\text { Deviation }\end{array}$ \\
\hline & Control & 15 & 1.60 & .632 & 1.80 & .775 \\
\hline & Total & 30 & 1.63 & .809 & 2.30 & .952 \\
\hline \multirow{3}{*}{$\begin{array}{l}\text { Voice of the advanced } \\
\text { writing course } \\
\text { students }\end{array}$} & Experimental & 15 & 1.73 & .704 & 2.47 & .640 \\
\hline & Control & 15 & 1.47 & .516 & 1.93 & .799 \\
\hline & Total & 30 & 1.60 & .621 & 2.20 & .761 \\
\hline \multirow{3}{*}{$\begin{array}{l}\text { Word choice adapted } \\
\text { by the students }\end{array}$} & Experimental & 15 & 1.60 & .737 & 3.00 & .756 \\
\hline & Control & 15 & 1.40 & .507 & 2.33 & .976 \\
\hline & Total & 30 & 1.50 & .630 & 2.67 & .922 \\
\hline \multirow{3}{*}{ Sentence Structure } & Experimental & 15 & 1.47 & .743 & 2.80 & .414 \\
\hline & Control & 15 & 1.33 & .488 & 1.80 & .775 \\
\hline & Total & 30 & 1.40 & .621 & 2.30 & .794 \\
\hline \multirow{3}{*}{$\begin{array}{l}\text { Content of the writing } \\
\text { topic }\end{array}$} & Experimental & 15 & 1.80 & .775 & 2.47 & .834 \\
\hline & Control & 15 & 1.87 & .352 & 1.80 & .775 \\
\hline & Total & 30 & 1.83 & .592 & 2.13 & .860 \\
\hline
\end{tabular}

Table 4 reveals that there are differences in the mean scores of students of both groups (experimental and control) in the pre and post measurement of the writing dimensions between the experimental and control group, and to test whether these differences were statistically significant $(\alpha=0.05)$, Multivariate analysis of Covariance (MANCOVA) test was applied. Results are presented in Table 5.

Table (5) Multivariate test of the writing dimensions according to the teaching method

\begin{tabular}{|c|c|c|c|}
\hline & Value & F & Sig \\
\hline Hotelling's Trace & 0.797 & 3.668 & 0.014 \\
\hline
\end{tabular}

Table 5 reveals that there are significant differences in the total mean scores of students on the writing measure dimensions according to the teaching method, (Hotelling's Trace value was 0.797$)$.

To test if the differences in the mean scores of students regarding each of the writing measure dimensions were statistically significant $(\alpha=0.05)$, Multivariate Analysis of Covariance (MANCOVA) was applied. Results are presented in Table (6) 
Journal of Social Sciences (COES\&RJ-JSS), 7(3), pp.187-214

Table (6) Multivariate Analysis of Covariance (MANCOVA) for the writing dimensions due to the teaching method

\begin{tabular}{|c|c|c|c|c|c|c|c|}
\hline Source & Dimensions & $\begin{array}{l}\text { Type III } \\
\text { Sum of } \\
\text { Squares }\end{array}$ & Df & $\begin{array}{l}\text { Mean } \\
\text { Square }\end{array}$ & $\mathbf{F}$ & Sig. & $\begin{array}{l}\text { Partial Eta } \\
\text { Squared }\end{array}$ \\
\hline \multirow{5}{*}{ Pre } & $\begin{array}{l}\text { Organization of the } \\
\text { writing topic }\end{array}$ & .930 & 1 & .930 & 1.406 & .246 & .049 \\
\hline & $\begin{array}{l}\text { Voice of the advanced } \\
\text { writing course students }\end{array}$ & 2.584 & 1 & 2.584 & 5.775 & .023 & .176 \\
\hline & $\begin{array}{l}\text { Word choice adapted by } \\
\text { the students }\end{array}$ & 2.027 & 1 & 2.027 & 2.835 & .104 & .095 \\
\hline & Sentence structure & 1.714 & 1 & 1.714 & 5.092 & .032 & .159 \\
\hline & $\begin{array}{l}\text { Content of the writing } \\
\text { topic }\end{array}$ & 4.760 & 1 & 4.760 & 9.610 & .004 & .263 \\
\hline \multirow{5}{*}{ Group } & $\begin{array}{l}\text { Organization of the } \\
\text { writing topic }\end{array}$ & 6.743 & 1 & 6.743 & 10.189 & $.004 *$ & .274 \\
\hline & $\begin{array}{l}\text { Voice of the advanced } \\
\text { writing course students }\end{array}$ & 1.559 & 1 & 1.559 & 3.484 & .073 & .114 \\
\hline & $\begin{array}{l}\text { Word choice adapted by } \\
\text { the students }\end{array}$ & 2.669 & 1 & 2.669 & 3.733 & .064 & .121 \\
\hline & Sentence structure & 6.522 & 1 & 6.522 & 19.380 & $.000^{*}$ & .418 \\
\hline & $\begin{array}{l}\text { Content of the writing } \\
\text { topic }\end{array}$ & 2.369 & 1 & 2.369 & 4.783 & $.038 *$ & .150 \\
\hline \multirow{5}{*}{ Error } & $\begin{array}{l}\text { Organization of the } \\
\text { writing topic }\end{array}$ & 17.870 & 27 & .662 & & & \\
\hline & $\begin{array}{l}\text { Voice of the advanced } \\
\text { writing course students }\end{array}$ & 12.082 & 27 & .447 & & & \\
\hline & $\begin{array}{l}\text { Word choice adapted by } \\
\text { the students }\end{array}$ & 19.306 & 27 & .715 & & & \\
\hline & Sentence structure & 9.086 & 27 & .337 & & & \\
\hline & $\begin{array}{l}\text { Content of the writing } \\
\text { topic }\end{array}$ & 13.373 & 27 & .495 & & & \\
\hline \multirow[t]{5}{*}{ Total } & $\begin{array}{l}\text { Organization of the } \\
\text { writing topic }\end{array}$ & 26.300 & 29 & & & & \\
\hline & $\begin{array}{l}\text { Voice of the advanced } \\
\text { writing course students }\end{array}$ & 16.800 & 29 & & & & \\
\hline & $\begin{array}{l}\text { Word choice adapted by } \\
\text { the students }\end{array}$ & 24.667 & 29 & & & & \\
\hline & Sentence structure & 18.300 & 29 & & & & \\
\hline & $\begin{array}{l}\text { Content of the writing } \\
\text { topic }\end{array}$ & 21.467 & 29 & & & & \\
\hline
\end{tabular}

\footnotetext{
* Significant $(\alpha=0.05)$.
} 
Table 6 shows that (F) value for the dimension "organization of the writing topic" is (10.189). Which is a statistically significant value at significance level ( $\alpha=0.05)$, and for the dimension a voice of the writing course students (3.484) which is statistically insignificant at significance level (0.05), and for word choice adapted by the students (3.737) which means a statistically insignificant value at significance level $(\alpha=0.05)$. And for the sentence structure dimension (19.380) which is a statistically significant value for the content of the writing topic (4.7383). Which is a statistically significant value?

The rustles of study revealed statistically significance on all the writing measure fields according to the teaching method between the experimental and control group. To know in favor of which group these differences were, the Adjusted mean scores and the standard errors were obtained, Results are presented in Table (7)

Table (7) Adjusted mean scores and the standard errors for the writing dimensions due to the teaching method between the experimental and control groups

\begin{tabular}{|l|c|c|c|}
\hline \multicolumn{1}{|c|}{ Dimensions } & Group & Mean & Std. Error \\
\hline \multirow{2}{*}{$\begin{array}{l}\text { Organization of the } \\
\text { writing topic }\end{array}$} & Experimental & 2.778 & .211 \\
\cline { 2 - 4 } & Control & 1.822 & .211 \\
\hline \multirow{2}{*}{ Sentence structure } & Experimental & 2.770 & .150 \\
\cline { 2 - 4 } & Control & 1.830 & .150 \\
\hline \multirow{2}{*}{$\begin{array}{l}\text { Content of the } \\
\text { writing topic }\end{array}$} & Experimental & 2.417 & .182 \\
\cline { 2 - 4 } & Control & 1.850 & .182 \\
\hline
\end{tabular}

Table 7 shows the Adjusted means of the writing dimensions and the measure's total degree came in favor of the experimental group, which means that the experimental group performance was better than the performance of the control group on the writing dimensions for all of the three dimensions.

And to know the effect size, Eta square is obtained, and Table 6 shows that the effect size of the organization of the writing topic dimensions reached $(0.274)$ which means that $(27.4 \%)$ of the variance in the writing topic dimensions scores attributes to the teaching method, and the effect size of the sentence structure dimension reached $(0.418)$ which means that $(41.8 \%)$ of the variance in the sentence structure dimension attribute to the teaching method, and the effect size of the dimension content of the writing topic reached $(0.150)$ which means that $(15 \%)$ of the variance in the content of the writing topic attribute to the teaching method

total score for writing skills

Means and standard deviations were calculated on pre and post measure of the writing total score according to the teaching method between the two groups, the control and experimental. Results are presented in Table 8. 
Table (8) Means and standard deviations of the pre and post measure of the writing total score due to the teaching method.

\begin{tabular}{|c|l|c|c|c|c|c|}
\hline \multirow{2}{*}{ Dimensions } & \multirow{2}{*}{ Group } & \multirow{2}{*}{$\mathbf{N}$} & \multicolumn{2}{c|}{ Pre test } & \multicolumn{2}{c|}{ Post test } \\
\cline { 4 - 7 } & & & Mean & $\begin{array}{c}\text { Std. } \\
\text { Deviation }\end{array}$ & Mean & $\begin{array}{c}\text { Std. } \\
\text { Deviation }\end{array}$ \\
\hline \multirow{3}{*}{ Total } & Experimental & 15 & 8.33 & 3.658 & 13.53 & 2.066 \\
\cline { 2 - 7 } & Control & 15 & 7.67 & 1.291 & 9.67 & 3.904 \\
\cline { 2 - 7 } & Total & 30 & 8.00 & 2.716 & 11.60 & 3.645 \\
\hline
\end{tabular}

Table 8 reveals that there are differences in the mean scores of students of both groups (experimental and control) in the pre and post measurement of the writing total score of the measure between the experimental and control group, and to know the significance of these differences.

To test whether these differences were statistically significant $(\alpha=0.05)$, One-way Analysis of Covariance (ANCOVA) test was applied. Results are presented in Table 9.

Table (9) One-way analysis of Covariance (ANCOVA) for the writing measure total score due to the teaching method

\begin{tabular}{|l|c|c|c|c|c|c|}
\hline Source & $\begin{array}{c}\text { Type III } \\
\text { Sum of } \\
\text { Squares }\end{array}$ & Df & $\begin{array}{c}\text { Mean } \\
\text { Square }\end{array}$ & F & Sig. & $\begin{array}{c}\text { Partial Eta } \\
\text { Squared }\end{array}$ \\
\hline Pre & 56.053 & 1 & 56.053 & 6.974 & .014 & .205 \\
\hline Group & 91.625 & 1 & 91.625 & 11.400 & $.002 *$ & .297 \\
\hline Error & 217.014 & 27 & 8.038 & & & \\
\hline Total & 385.200 & 29 & & & & \\
\hline
\end{tabular}

Table 9 reveals that there are statistically significant differences in the mean scores of students of both groups regarding the writing total scores, shows that $(F)$ value reached for total score (11.400), which is statistically significant $(\alpha=0.05)$, which means the presence of differences with statistically significance on all the writing total score according to the teaching method between the experimental and control group.

To know in favor of which group these differences were, adjusted mean scores and standard errors were obtained. Results are presented in Table10.

Table (10) Adjusted mean scores and standard errors of the writing total score due to the teaching method between the experimental and control groups

\begin{tabular}{|c|c|c|c|}
\hline Fields & Group & Mean & Std. Error \\
\hline \multirow{2}{*}{ Total score } & Experimental & 13.361 & .735 \\
\cline { 2 - 4 } & Control & 9.839 & .735 \\
\hline
\end{tabular}


Table 10 shows the Adjusted mean of the writing total score was in favor of the experimental group, which means that the experimental group performance was better than the performance of the control group on the writing for total score.

To know the effect size, Eta square is obtained, and table (9) shows that the effect size of total score the effect size reached $(0.297)$, which means that $(29.7 \%)$ of the variance in the total scores of the measure attribute to the teaching method.

Are there any statistically significant differences $(\alpha=0.05)$ in the writing mean scores of sophomore students that can be attributed to the effect of teaching method (i.e. Facebook vs. conventional)?

Result of this question revealed that there was statistically significance for (organization of the writing topic, sentence structure, content of the writing topic), and for total score which is a value with statistically significance of significance level (0.05), the presence of differences with statistically significance for three dimensions attributed to the teaching method between the experimental and control group, come in favor of the experimental group.

And there was not statistically significance for dimensions (Voice of the advanced writing course students and Word choice adapted by the students) due to teaching method.

The experimental group benefited from using Facebook in developing and improving their writing skills, through the use of the vocabulary and typing them on the mobile phone or the computer device, and through correcting the spelling of the words by using the programs related to the Facebook site, in which on the other hand improves the writing skills. This can be attributed to the students attempt not to make errors in their writing which gives positive image about them as a university student in the English department comparing to the control group who were taught by the traditional method.

It's worth mentioning that using Facebook which has multiple choice and audio influences, photos and different models expanded the students 'perceptive and improved their ability to develop their writing skills generally.

On the other hand, the result of the first question agree with similar results obtained from several studies conducted by researchers who have addressed the effect of using Facebook in the teaching and learning process. Such studies include Yunus and Salehi (2012) study which investigated the effectiveness of Facebook Groups on teaching and improving writing. The Findings of this study showed that Facebook is an effective tool in improving the third year university students writing skills.

Results of a study conducted of Rodliyah ( 2015), which investigated the effect of using Facebook closed group to improve EFL students, writing from the second, Third and Fourth year students of English Education Department, come in agreement with the results reached by this current study. 
While Hussain and Al-Choul,( 2014) study has addressed the effectiveness of using Facebook on the Ninth grade students' achievement of English Language in Jordan, In spite of the difference of the participants' gender, since this study has included only the female students, the results of this study showed statistically significant differences between the mean of students in the experimental group studied by the Facebook method and the mean of the control group in favor of the experimental group. This result supports the results reached by this study.

Results of this study regarding the effect of using Facebook for discussion of English grammar and improving English writing skills came in alignment with a study conducted by Thanawan and Puxhale, (2012), which addressed the same topic in the Thailand environment. Results of this study showed that English grammar worth promoting for discussions on Facebook, because there were correlations between the gain scores in the grammar and writing skills.

These results also showed that the students had positive attitudes towards using Facebook as a mean of learning grammar and writing. Also, results of this study agree with a study results obtained by Panawan,( 2011), which investigated the students' opinions on the impact of using Facebook for English Reading and Writing skills improvement, the study found out that although Facebook was found to be helpful in learning English as it offers the opportunities to use English.

\section{Results related to the second question}

Are there any statistically significant differences $(\alpha=0.05)$ in the writing mean scores of sophomore students that can be attributed to the effect of the teaching method (i.e. Facebook vs. conventional)?

To answer this question, means and standard deviations were calculated on pre and post measure of the vocabulary total score according to the teaching method between the two groups, the control and experimental. Results are presented in Table 11.

Table (11) Means and standard deviations of the pre and post for the vocabulary due to the teaching method

\begin{tabular}{|c|c|c|c|c|c|c|}
\hline \multirow{2}{*}{ Field } & \multirow{2}{*}{ Group } & \multirow{2}{*}{$\mathbf{N}$} & \multicolumn{2}{|c|}{ Pre test } & \multicolumn{2}{c|}{ Post test } \\
\cline { 4 - 7 } & & & $\begin{array}{c}\text { Std. } \\
\text { Deviation }\end{array}$ & Mean & $\begin{array}{c}\text { Std. } \\
\text { Deviation }\end{array}$ \\
\hline \multirow{3}{*}{ Vocabulary } & Experimental & 15 & 16.87 & 4.518 & 22.27 & 2.865 \\
\cline { 2 - 7 } & Control & 15 & 13.80 & 5.634 & 18.73 & 4.334 \\
\cline { 2 - 7 } & Total & 30 & 15.33 & 5.254 & 20.50 & 4.032 \\
\hline
\end{tabular}

Table 11 reveals that there are differences in the mean scores of students of both groups (experimental and control) in the pre and post measurement for the vocabulary measure between the experimental and control group. To test whether these differences were statistically significant $(\alpha=0.05)$, One-way Analysis of Covariance (ANCOVA) test was applied. Results are presented in Table 12 
The effect of using facebook on improving English language writing skills...

Table (12) one - way analysis of Covariance (ANCOVA) for the vocabulary due to the teaching method

\begin{tabular}{|c|c|c|c|c|c|c|}
\hline Source & $\begin{array}{c}\text { Type III } \\
\text { Sum of } \\
\text { Squares }\end{array}$ & Df & $\begin{array}{c}\text { Mean } \\
\text { Square }\end{array}$ & F & Sig. & $\begin{array}{c}\text { Partial Eta } \\
\text { Squared }\end{array}$ \\
\hline Pre & 308.672 & 1 & 308.672 & 120.445 & .000 & .817 \\
\hline Group & 16.207 & 1 & 16.207 & 6.324 & $.018^{*}$ & .190 \\
\hline Error & 69.195 & 27 & 2.563 & & & \\
\hline Total & 471.500 & 29 & & & & \\
\hline
\end{tabular}

* Significant $(\alpha=0.05)$.

Table 12 reveals that there are statistically significant differences in the mean scores of students of both groups with regard to vocabulary shows that (F) value reached for vocabulary for the teaching method reached (6.324), which is a statistically significant value at significance level (0.05), which means the presence of differences with statistically significance in vocabulary due to the teaching method

\section{Conclusion}

It can be concluded that using Facebook in teaching writing skills and vocabulary enrichment by university students have recognizable effect on improving these skills and increase the list of vocabulary on the students' memory. The study on the whole showed very promising results in using Facebook to benefit teaching and learning. The results of this study indicates that using Facebook is an ideal way to encourag students to write confidentially about things they enjoy, and this improves writing skills. The study showed that successful social networks such as Facebook can be highly influential environments for much learning. So this study showed positive effect of using this social networking site (Facebook) on improving English language writing skills and vocabulary enrichment of the experimental group, compared to the control group. Also, in line with Obeidat et al. (2013), future research could investigate how university students could reap the benefits from using Facebook applications in commercial sectors such as banks, hotels, among others.

\section{Recommendations}

In light of the results that the researcher reached, she recommends the following:

1- Encourages university instructors to use Facebook in writing courses.

2- The necessity for conducting training courses to address the Facebook issue regarding its importance, components, strategies and the ways to train in using it in teaching, which will help the teachers in using the Facebook to equip the students with the different skills, like the writing skills.

3- $\quad$ The necessity for the educators and educational policy makers in curriculum and teaching methods to prepare lessons about using Facebook in teaching writing and vocabulary. 
4- $\quad$ Preparing the educational publications for teachers and the students to gain more awareness about Facebook, and its' applied methods, and features, and the role of the teacher and the student in this process.

5- Conducting more studies to confirm the importance of Facebook in developing other skills, such as the reading skills.

\section{References}

Ada, A. \& Campoy, F. I. (2004). Authors in the Classroom: A Transformative Education Process. Boston: Pearson Education, Inc.

Ahmad, M. (2016). Using Facebook to develop grammar discussion and writing skills in English as a foreign language for university students, sino-us English Teaching, 8(12): 932952.

Al-Abdallah, M. (2005). Communication and Democracy, 1st ed. Beirut: Dar Al-Nahda AlArabiyah for Printing, Publication and Distribution.

Alananzeh ,O,. Amyan,M,.O ALghaswyneh,O,. Shatnawi,H,. Jawabreh,O.(2015). Managing Promoting Tourism Product of the Golden Triangle in Jordan, International Journal of Humanities and Social Science,5(9),pp. 197- 207.

Al-Ananzeh, S. (2011). Saudi Students Attitudes, Beliefs and preferences towards online cooperative learning, Unpublished Doctoral Dissertation. Wayne State University, Detroit, Michigan. Retrieved 10-3-2017 From: http://search.proquest.comeezproxy. yu.edu.jo.

Al-Azza, F., Atameemi, A \& Al-Qatawneh, M. (2004). Computer Skills, Arabic Edition, Amman; Dar Al-Yazoori for Publication and Distribution.

Alkhader, M. (2015). The Impact of Using the Social Nnetworking Facebook site on Improving Academic Writing Skills and Reflective Thinking of University of Jordan Students, Unpublished Doctoral Dissertation, University of Jordan, Amman, Jordan.

ALsarayreh,M,. Jawabreh,O,. Jaradat,M,. ALamro,S,.(2011). Technological Impacts on Effectiveness of Accounting Information Systems (AIS) Applied by Aqaba Tourist Hotels, European Journal of Scientific Research, Vol.59 No.3,pp.361-369

Alsawaeer, H. (2014). Motives of the University Students and the Schools' Students for Using Social Network (Facebook) And Its Relationship With Their Academic Achievement, Unpublished Master Thesis, University of Jordan, Amman, Jordan.

Anderson, C. (2000). How's It Going? A Practical Guide to Conferring with Student Writers. Portsmouth, NH: Heinemann. 
Arroyo, C.(1992).What is the effect of extensive use of computers on the reading achievement score of seventh grade students? (ERIC Document Reproduction Service No.353544).

Bani Abdelrahman, A. (2005). The use of instructional technology in EFL: Attitudes of Jordanian teachers of English in Irbid. Mu'tah Lil-Bohooh Wad-Dirasat: Humanities and Social Studies

Bani Hani, W. (2010). Using and Employing Teaching Techniques in the Classroom, Amman : Dar Alam Al-Thaqafa for Publication and Distribution.

Barnett, W., Leslie, M. and Harkey, M. (2006). Facebook, Stanford graduate school, case E-220.

Beauvois, M, \&Eledge, J. (1996). Personality types and mega bytes: Students' attitudes toward computer mediated communication (CMC) in the language classroom. CALICO Journal, 13(2): 27-46.

Bincena, H and Cavus, N. (2011). Social Network sites usage habits of undergraduate students: case of Facebook, social and behavioral sciences, 28(1): 943-947.

Boyd, D \& Ellison, M. (2007). Social Networks Site: Definition, History, and Scholarship Journal of Computer - Mediated Communication (on-line), 13(1).

Calkins, L. (1994). The Art of Teaching Writing. Canada: Irwin Publishing.

Charles, M. (1990). Responding to Problems in Written English Using a Student Selfmonitoring Technique. ELT. 44(4), 286-293.

Dede, C. (1998). Six Challenges for Educational Technology. An extended version of this draft paper appeared in 1998 ASCD Yearbook, Learning with Technology.: In: Retrieved 15-12-2016 from http://www.virtual.gmu.edu/ss research /cd papers/

DenBeste, M. (2003). 'Powerpoint, technology and the Web: More than just an overhead projector for the new century. History Teacher,36 (4), 491-505.

Desberg, P. (1994). Hyper interactive CAl: Using Hyper Card to Develop Assisted Instruction. Boston: Allyn and Bacon Press.

Fernandiz, A. and Sabirwal, R. (2014). Knowledge management the systems and the process, New York: M. E. Sharpe, INC, Armonk,.

Gamble, C \& Wilkins, M (2012). Students Attitudes and perceptions of using FaceBook for language learning. Kwansei, Japan: Gakuin University.

Grabner, S. (2010). Web 2.0 Social Networks: The Role Trust. Journal of Business Ethics, $90: 505-525$. 
Graham, C. (2005). Blending Learning Systems: Definition of Blended Learning Global Perspectives, Local Design.

Greenall, S. and Swan, M. (1992). Effective Reading: Reading Skills for Advanced Students. 6th pr. The Press Syndicate of the University of Cambridge,.

Greenfield, R (1999). Collaborative e-mail exchange for teaching secondary ESL: a case study in Hong Kong. Language Learning and Technology, 7(1): .40-20.

Haider, M and Ackhter, E. (2012). Extensive Reading in EFL Classroom at Secondary Classrooms in Bangladesh: Current Practices and future Possibilities international Educational Studies, 5(3): 126-131.

Hobbs, R.; Renee, R. and Frost, R. (2003). Measuring the acquisition of media-literacy skills. Language Teaching, 37(2): 128.

Hulstijn, J . (2001). The use of computer technology in experimental studies of second language acquisition: A survey of some techniques and some ongoing studies. Language Learning and Technology, 3(2),32-43.

Hussain, J and Al-Ghoul, E (2014). The Effectiveness of Using Facebook on the Ninth Grade Students` Achievement of English in Jordan. Unpublished doctoral Dissertation, Hashemite University, Zarqa, Jordan .

Ibrahim, M. (2013). The Effect of using Facebook on Improving Students' Writing Skill in English, Unpublished Master Thesis, An- Najah National University, Nablus, Palestine.

Jayyusi, S. (1990). English Language Curriculum and Its General Guidelines for Basic Education Stage. Jordan: Ministry of Education.

Johnson, D. and Johnson, T. (1988). Critical Thinking through Structured Controversy. Educational Leadership. 45(8): 1-22.

Kokkas, N. (2000). Internet Activities in the EFL Classroom. Retrieved from Ugr/bridges/page $13 \mathrm{html}$.

Kotler,Ph \& Keller,N (2016). Marketing management, 5th Global edition, England: Person Education limited.

Lee, I. (2003). Error correction in L2 secondary writing classrooms. Language Teaching, $37(2): 112$.

Mahdeen, Radwan (2012). Advanced writing, Amman: University of Jordan

Makawi, H \& Al-Sayed.L. (2009). Communication and its Contemporary Theories. 8th ed. Cairo: Aldar Al-Masriya Al-Lobnaniya for Publication and Distribution. 
Masa'deh, R., Shannak, R., and Maqableh, M. (2013). A structural equation modeling approach for determining antecedents and outcomes of students' attitude toward mobile commerce adoption. Life Science Journal, 10(4): 2321-2333.

Medina, M., (2002). A Study of Hispanic EFL Students Learning English within a CALL Classroom: Student Introspection on Learning, Technology, and Community. Unpublished doctoral Dissertation. Indiana University of Pennsylvania, Indiana, USA.

Mohammad .A, Omar .J, Khalid A, Mohammed .A.(2011 ). Tourism Promotion through the Internet (Websites) (Jordan as a Case Study), Asian Social Science, Vol. 7, No. 6; doi:10.5539/ass.v7n6p125.

Morad, A. (2004). Intelligent Schools. Alexandria : Al-Baha company for software and computer and electronic publication.

Nolan, P (2011) . Students` Perceptions on the Impact of Using Facebook for English Reading and Writing Skill Improvement. Unpublished Master Thesis, Thammasat University Bangkok, Bangkok, Thailand.

Nunan, O. (2003). The impact of English Language as a Global Language on Educational Policies and Practices in the Asia-Pacific Region, TESOL Quarterly, 37(1), 589-613.

Obeidat, B., El-Rimawi, S., Maqableh, M., and Al-Jarrah, I. (2013). Evaluating the profitability of the Islamic banks in Jordan. European Journal of Economics, Finance and Administrative Sciences, 56: 27-36.

Reeves, T. (1999). A Research Agenda for Interactive Learning in the New Millennium, Proceeding of ED-MEDIA World Conference on Educational Multimedia, Hypermedia and Telecommunication. Ed. Collis and R, Washington, USA

Roblyer, M.; Mcdoniel, . Webb, M. Herman, J \&Wittly, J. (2010). Findings on and perceptions of social networking sites, the Internet and higher education, 13(3), 134-140.

Rodliyan , R (2015) Using a FaceBook closed group to improve EFL students. Writing, Indonesia: university of Pendidikan.

Rumelhart, D, (1977). Toward an interactive model of reading. In S. Dornic, Attention and Performance, Hillsdale, NJ: Lawrence Erlbaum. Sciences Series, $\quad$ 20(2): 9-3.

Sergeant S. (2001). CALL Innovation in the English Language Curriculum: Innovation in English Language Teaching. London: Rutledge New Fetter Lane.

Suker, S \& Nordin, N (2014) . Effect of Facebook Collaborative Writing Groups on ESL Undergraduate Writing Performance, 2(2): 1-17. 
Suthiwartharueput, Th \& Wasanasomsith, P (2012). Effect of using FaceBook as a medium for discussions of English grammar and writing of FL students. Electronic Journal of Foreign language teaching, 9(2): 194-214.

Thompson, C. (2008). Brave new world of digital intimacy, The New York Times, Review 44(3): 1-34.

Ulusu, Y. (2010) Determinant Factors of Time Spent on Facebook: Brand community engagement and usage types, Journal of Yasar University, 18 (5): 2949-2957.

Wang, T. \& Li, L. (2008). Understanding international postgraduate research students' challenges and pedagogical needs in thesis writing, international journal of pedagogies and learning, 4(3): 88-96.

Woolfolk, A. (2001). Educational Psychology. Boston: Allyn and Bacon.

Yunus, M., and Salehi, H., (2012). The Effectiveness of Facebook Groups on Teaching and Improving Writing: Students Perceptions. International Journal of Education and Information Techniques, 1(6): 1-41.

Zamel, V. (1987). Recent Research on Writing Pedagogy. TESOL Quarterly, 21(4): 190223. 